International Research Journal of Management, IT \& Social Sciences
Available online at https://sloap.org/journals/index.php/irjmis/
Vol. 6 No. 1, January 2019, pages: $86 \sim 94$
ISSN: 2395-7492
https://doi.org/10.21744/irjmis.v6n1.598

\title{
Service Satisfaction towards Student Achievements of Dual Degree Program Stikom Bali
}

\author{
Ni Putu Putri Ayu Wijayanthi ${ }^{a}$ \\ I Nengah Dasi Astawa ${ }^{b}$ \\ Ida Bagus Raka Suardana ${ }^{c}$ \\ Ni Nyoman Sunariani ${ }^{\mathrm{d}}$
}

Article history:

Received: 27 July 2018

Accepted: 30 November 2018

Published: 30 January 2019

\section{Keywords:}

academic services;

administrative services;

leader policy;

student achievement;

student satisfaction;

\begin{abstract}
The study was intended to examine the factors that influence student satisfaction and achievement. Based on the facilities and infrastructure variables, administrative services, and leader policies as independent variables. The student satisfaction variable was as intermediary variable and student achievement as the dependent variable. The population used in the present study were all active students in STMIK STIKOM Bali Dual Degree program studies class of 2014-2018 with a total sample of 188 people. Data collection was conducted by distributing a list of statements in the questionnaires form. The data analysis technique used to analyze data was Path Analysis. The calculation of path coefficients was used Amos software. It was concluded that the facilities and infrastructure variables had a negative and no significant effect on student satisfaction, academic service variables had a positive and not significant effect on student satisfaction while the leadership policy variable had a positive and significant effect on student satisfaction. In the second equation of variables facilities and infrastructure have a positive and not significant effect on student achievement, academic service variables have a positive and not significant effect on student achievement, leadership policy variables have a positive and significant effect on student achievement, and student satisfaction variables have a positive and significant effect on student achievement.
\end{abstract}

2395-7492@ Copyright 2019. The Author. This is an open-access article under the CC BY-SA license (https://creativecommons.org/licenses/by-sa/4.0/) All rights reserved.

\section{Author correspondence:}

Name of Author,

Universitas Pendidikan Nasional, Denpasar, Indonesia

Jl. Waturenggong No.164 Denpasar, Bali.

Email address: putriawijayanthi@gmail.com

\footnotetext{
${ }^{\text {a }}$ Universitas Pendidikan Nasional, Denpasar, Indonesia

${ }^{\mathrm{b}}$ Universitas Pendidikan Nasional, Denpasar, Indonesia

${ }^{c}$ Universitas Pendidikan Nasional, Denpasar, Indonesia

${ }^{\mathrm{d}}$ Universitas Pendidikan Nasional, Denpasar, Indonesia
} 


\section{Introduction}

Facilities and infrastructure services are the focus of STIKOM Bali organizers. The students who are targeted and consumers of the service facilities and infrastructure have high hopes of being able to obtain quality facilities and infrastructure services. Therefore, the expectations of these students can be fulfilled and achieve a high degree of satisfaction. STIKOM Bali as an IT campus prioritizes facilities and infrastructure such as software (applications) that support student learning processes and hardware (devices) to support the practical needs of the students in the laboratory.

Learning achievement is an important indicator to measure the success of the teaching and learning process. It is at the core of the overall education process with lecturers as holders of important/main roles supported by facilities and infrastructure, as well as the leader's policies. The learning achievements of STIKOM Bali students not only succeed in Bali locally but are often the spotlight in the National level. The good student achievement can increase satisfaction and trust from the community. It is marked by the presence of mouth of mouth communication about positive things regarding service providers, in this case, universities. Based on this explanation, the researchers were very interested in conducting a study in order to determine the effect of academic services on student achievement in the Dual Degree program.

\section{Literature Review}

The educational process consists of several elements that influence each other. These elements include educators, students, subject matter, learning facilities, and infrastructure, etc. According to Syaodih (2009), learning facilities are all that needed in the teaching and learning process both stay and not forwarding, thus, the goals of education are run smoothly, regularly, effectively and efficiently. Based on the above opinion, it can be stated that all learning infrastructure facilities are a facility needed for students to achieve learning goals through learning activities in the form of investigations and discoveries to gain an understanding of the problems being studied.

Discussing the problem of the academic services, of course, it will not be separated regarding public services. Due to the academic services also involve public services in special fields. According to Moenir (1995), the public service is an activity conducted by a person or group of people on a material basis through certain systems, procedures, and methods in the context of efforts to meet the interests others in accordance with their rights.

The leadership itself according to Bass (2011), is an interaction between members of a group. Therefore, the leaders are agents of the reformers, agents of change, people whose behavior will influence others. It is more than other people's behavior that affects them. The leadership itself arises when one group member changes the motivation of member's interests others in the groups (Engkosworo \& Komariah, 2011).

According to Sugito (2008), student satisfaction is a condition of fulfilling the wishes, hopes, and needs of students (in Srinadi, 2008). Student satisfaction is a positive attitude of the students towards the services of the higher education institutions. Due to the compatibility between the expectations of service compared to the reality they receive (Sopiatin, 2010). According to Ahmadi (2003), explained that learning achievement is an activity that is able to satisfy a need, then, there is a large tendency to repeat it. The source of learning reinforcement can be extrinsic (value, recognition, and appreciation) and can be intrinsic (enthusiasm to investigate, interpret situations). Slamet (2003), stated that learning achievement is a change that someone achieves after following the learning process.

\section{Materials and Methods}

This research was conducted at STMIK STIKOM Bali. The population was the students of STMIK STIKOM Bali Dual Degree program from 2014 to 2018 amounted 188 people. The sample used was the total population i.e., 188 people. Data was collected using documentation and questionnaire instruments. All variables were measured using the internal scale in the form of an agree-disagree scale with a Likert scale. The author distributed 188 initial questionnaires to respondents and the questionnaire was then tested by theory-based model development. Wherein, this step was the search or development of a model that has strong theoretical justification. After that, the model was empirically validated through computation of the AMOS program. The initial step in AMOS was the development of a hypothetical model, namely the model development based on a theory or concept or known as modeling with a confirmatory approach. After the model was formed then it was confirmed based on empirical data through AMOS.

Wijayanthi, N. P. P. A., Astawa, I. N. D., Suardana, I. B. R., \& Sunariani, N. N. (2019). Service satisfaction towards student achievements of dual degree program Stikom Bali. International Research Journal of Management, IT and 
Therefore, the path diagram was developed (path diagram). In the second step, the theoretical model that has been built in the first step will be illustrated in a path diagram. It will make it easier for the researchers to see the causality relationships that they want to test. Based on the theory, a structural model was then made and the independent variables and dependent variables were then determined in the direction of the arrow according to the causality direction. If, this measurement model was incorporated into the structural model, thus, the path diagram and measurement model was in an integrated manner. Next, the convert of the path diagram was based on the equation. In the path diagram, it was converted into structural equations, with formulas (Ferdinand, 2006), as follows:

\section{Endogenous Variable $=$ Exogenous Variable + Endogenous Variable + Error}

The last stage was evaluating the goodness of fit to get a valid outcome model. This stage required several assumptions, i.e., those relating to the model and the assumed parameter assumptions and hypothesis testing. The assumptions for the model in AMOS included that the relationship between variables was linear, and the model was additive. The parameter estimation assumptions and hypothesis testing were among the interdependent observation units, the number of samples was large enough to assume that the sample would approach the normal distribution.

\section{Conceptual Framework}

The conceptual framework of this research was formulated based on the results of the translation and research thinking concepts that were guided by the path of previous research as well as supporting theories related to this research. This research will be emphasized more on the influence of facilities and infrastructure variables, academic services, and leadership policies on student satisfaction and student achievement.

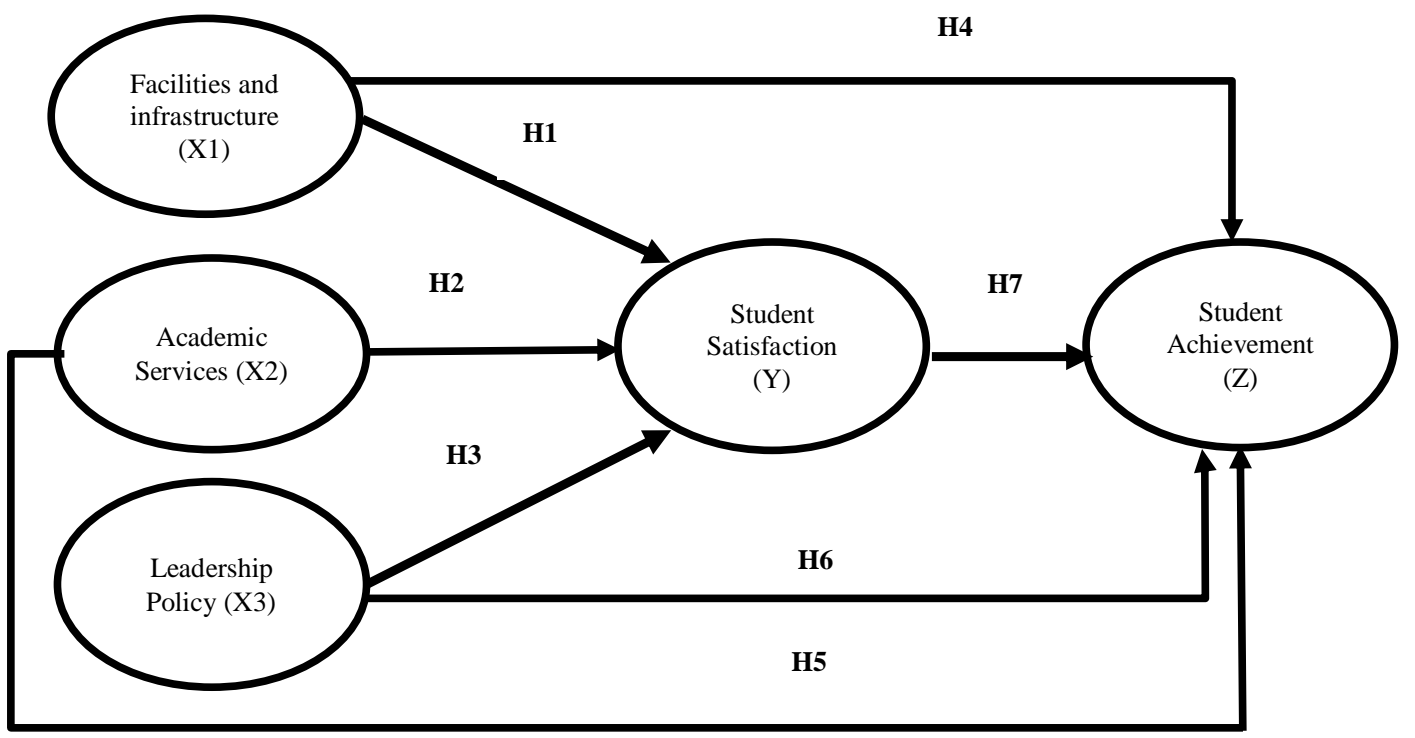

Figure 1. A conceptual model of variable relationship facilities, academic services, leadership policy toward student satisfaction and student achievement

The conceptual model in Figure 1 illustrates that the student satisfaction variable (Y) is influenced the facilities and infrastructure (X1) with the H1 hypothesis. Student satisfaction variable (Y) is also influenced the academic services (X2) with the H2 hypothesis. In addition, the variable student satisfaction was also influenced the leasership policy (X3) with the H3 hypothesis. Student achievement variable (Z) was also directly influenced the facilities and infrastructure (X1) with the H4 hypothesis and academic services (X2) with the H5 Hypothesis. As well as, the leadership policy (X3) that influenced achievement $(\mathrm{Z})$ directly with the H6 hypothesis. Furthermore, the influence of facilities and infrastructure, academic services, and leadership policies on satisfaction can be known by regression I. with $\mathrm{H} 7$ hypothesis. 
Research Hypothesis

H1: Facilities and infrastructure influence student satisfaction

H2: Academic services have an influence on student satisfaction

H3: Leadership policy influences student satisfaction

H4: Infrastructure has a direct influence on student achievement

H5: Academic services have a direct influence on student achievement

H6: Leadership policy influences student achievement

H7: Student satisfaction influences student achievement

\section{Results and Discussions}

Structural equations variable for facilities and infrastructure; academic service variables; leadership policy variables; student satisfaction variables; and student achievement variables,

a) $\mathrm{Y}=\gamma_{\mathrm{y} . \mathrm{x} 1} \mathrm{X} 1 \cdot \gamma_{\mathrm{y} \cdot \mathrm{x} 2} \mathrm{X} 2 \gamma_{\mathrm{y} \cdot \mathrm{x} 3} \mathrm{X} 3{ }_{+} \mathrm{e}_{1}, \rightarrow$ the direct influence of the facilities and infrastructure variables, academic services and leadership policies on student satisfaction.

b) $\mathrm{Z}=\gamma_{\mathrm{z} \times \mathrm{x}} \mathrm{X} 1 . \gamma_{\mathrm{z} . \mathrm{x} 2} \mathrm{X} 2 . \gamma_{\mathrm{z} \times 3} \mathrm{X} 3 \cdot \gamma_{\mathrm{z} . \mathrm{y} 1} \mathrm{Y}+\mathrm{e}_{1}, \rightarrow$ the direct influence of the variables included facilities and infrastructure, academic services, leadership policies and student satisfaction on student achievement.

The results of the regression coefficient calculation (regression weight) can be seen in the following table.

Table 1

Regression weights: (group number 1 - default model)

\begin{tabular}{|c|c|c|c|c|c|c|}
\hline & & Estimate & S.E. & C.R. & $\mathrm{P}$ & Label \\
\hline & $<---\quad$ X3 & .767 & .140 & 5.488 & $* * *$ & par_33 \\
\hline$Y$ & $<---\quad X 2$ & .018 & .060 & .307 & .759 & par_41 \\
\hline$Y$ & $<---\quad X 1$ & -.171 & .153 & -1.116 & .265 & par_42 \\
\hline Z & $<---\quad X 3$ & .334 & .117 & 2.849 & .004 & par_36 \\
\hline Z & $<---$ & .152 & .073 & 2.073 & .038 & par_37 \\
\hline Z & $<---\quad X 2$ & .006 & .045 & .132 & .895 & par_38 \\
\hline Z & $<---\quad X 1$ & .020 & .115 & .174 & .862 & par_39 \\
\hline
\end{tabular}

Table 2

Standardized regression weights: (group number 1 - default model)

\begin{tabular}{|c|c|c|}
\hline & & Estimate \\
\hline & $<---\quad$ X3 & .610 \\
\hline $\mathrm{Y}$ & $<---\quad X 2$ & .024 \\
\hline Y & $<---\quad X 1$ & -.100 \\
\hline $\mathrm{Z}$ & $<---\quad$ X3 & .388 \\
\hline $\mathrm{Z}$ & $<---\quad Y$ & .222 \\
\hline $\mathrm{Z}$ & $<---\quad X 2$ & .011 \\
\hline & $<---\quad X 1$ & .017 \\
\hline
\end{tabular}

Wijayanthi, N. P. P. A., Astawa, I. N. D., Suardana, I. B. R., \& Sunariani, N. N. (2019). Service satisfaction towards student achievements of dual degree program Stikom Bali. International Research Journal of Management, IT and Social Sciences, 6(1), 86-94. https://doi.org/10.21744/irjmis.v6n1.598 
Table 3

Standardized direct effects (group number 1 - default model)

\begin{tabular}{|r|rrrrr|}
\hline & $\mathrm{X} 2$ & $\mathrm{X} 3$ & $\mathrm{X} 1$ & $\mathrm{Y}$ & $\mathrm{Z}$ \\
\hline $\mathrm{Y}$ & .024 & .610 & -.100 & .000 & .000 \\
$\mathrm{Z}$ & .011 & .388 & .017 & .222 & .000 \\
\hline
\end{tabular}

\section{Contributions of Leadership Policy towards Student Satisfaction}

The empirical test results prove the influence of the leadership policy variable (X3) on the student satisfaction variable (Y) has an estimated standardized value (regression weight) of 0.610 with a CR (critical ratio/value equal to t-test value) of 5.488 with a probability value $* * *$. Value of C.R 5,488>2,000 and probability value $* * *<0.05$ means that the leadership policy variable (X3) has a positive and significant influence on student satisfaction (Y). In accordance with Iksan (2013), leadership policy (X1) has a direct causal influence on student satisfaction (Z) (partial testing). The results indicated that the policies that have been made by the leaders of STIKOM Bali are able to answer the rights needs of STIKOM Bali students, in the academic learning process, as well as self-development. It is obtained outside the learning process in the classroom.

\section{Contribution of Academic Service towards Student Satisfaction}

The empirical test results prove the influence of academic services variable (X2) on student achievement variable (Z) has a standardized estimate (regression weight) of 0.011 with a value of C.R (critical ratio/equal to t-test value) of 0.132 with a probability value of 0.895 . The value of C.R $0.132<2,000$ and the probability value of $0.895>0.05$ means that the academic services variable (X2) has a positive and not significant effect on student achievement (Z). The results indicated that the academic services of STIKOM Bali felt by dual degree program students are known to be good and able to answer the needs of students for fulfilling academic services, but there are some academic services that are felt by students of dual degree programs that result in a lack of significance of academic service contribution to satisfaction college student. In accordance with Tuerah (2015), in the second hypothesis testing the value of academic service quality was found to have a significantly positive influence on satisfaction.

\section{Contribution of Facilities and Infrastructure towards Student Satisfaction}

The empirical test results prove the influence of facilities and infrastructure variables (X1) on the student satisfaction variable (Y) has a standardized estimate (regression weight) of - 0.100 with a value of CR (critical ratio/equal to t-test value) of -1.116 with probability value is 0.265 . Value of C.R $-11116<2,000$ and probability value $0.265>0.05$ means that the facilities and infrastructure variables (X1) have a negative and not significant influence on student satisfaction (Y). Referring to the results that have been studied, Charolina (2008), in the results obtained that tangible elements or facilities and infrastructure have no influence on taxpayer satisfaction.

\section{Contribution of Leadership Policy towards Achievement}

The empirical test results prove the influence of the leadership policy variable (X3) on student achievement variable (Z) has a standardized estimate (regression weight) of 0.388 with a value of C.R (critical ratio/equal to t-test value) of 2.849 with a probability value of 0.004 . C.R 2,849> 2,000 and probability value $0.004<0.05$ means that the leadership policy variable (X3) has a positive and significant influence on student achievement (Z). In accordance with the research conducted by Supriady (2016), there was a positive contribution of leadership to student learning achievement, its validity, in other words, the higher leadership, the higher its contribution to student learning achievement.

\section{Contribution of Student Satisfaction towards Student Achievement}

The empirical test results prove the influence of the student satisfaction variable (Y) on student achievement variable $(Z)$ has an estimated standardized value (regression weight) of 0.222 with a CR (critical ratio) equal to 2.073 with a probability value of 0.038 . Value of C.R 2.073> 2,000 and probability value of $0.038<0.05$ means that the student satisfaction variable (Y) has a positive and significant influence on student achievement (Z). In accordance 
with the research conducted by Khulaimah (2009), there is an influence of student perceptions and student satisfaction about the competence of the accounting teachers towards student learning outcomes.

\section{Contribution of Academic Service towards Student Achievement}

The empirical test results prove the influence of the academic services variable (X2) on student achievement variable $(Z)$ has a standardized estimate (regression weight) of 0.011 with a value of C.R (critical ratio/equal to t-test value) of 0.132 with a probability value of 0.895 . Value of C.R $0.132<2,000$ and the probability value of $0.895>0.05$ means that the academic services variable (X2) has a positive and not significant influence on student achievement (Z). In accordance with the research conducted by Safi'I et al., (2015), that the analysis results of the level for the service quality performance at Kadiri University were felt by students, meanwhile, the service quality attributes were able to influence the level of the academic achievement of Kadiri University students.

\section{Contribution of Facilities and Infrastructure towards Student Achievement}

The empirical test results prove the influence of facilities and infrastructure variables (X1) on student achievement variable $(\mathrm{Z})$ has a standardized estimate (regression weight) of 0.017 with a value of CR (critical ratio/equal to t-test value) of 0.174 with a probability value of 0.862 . Value of C.R $0.174<2,000$ and probability value of $0.862>0.05$ means that the facilities and infrastructure variables (X1) have a positive and not significant influence on student achievement $(Z)$.

These results indicate that the facilities and infrastructure provided by STIKOM Bali, especially in supporting the learning process in the classroom and student self-development are felt to contribute. However, there are only a number of infrastructure facilities that have not been able to meet the needs of students and they feel needing to be improved again. Similarly, based on the results of this study, Wijaya (2011), obtained that there is a positive and significant relationship between learning facilities towards PLC learning achievement of class XI students of electrical engineering expertise studies program at SMK PIRI 1 Yogyakarta, in the academic year 2009/2010.

\section{Conclusion}

Based on the research results and discussion, it has been described, the following conclusions can be drawn.

1. The contribution of facilities and infrastructure variable (X1) has a negative and not significant influence on student satisfaction (Y). It shows that the facilities and infrastructures of STIKOM Bali that are felt by Dual Degree students are known to be unsatisfactory, therefore, they have not been able to contribute to feeling satisfied with students.

2. The contribution of academic services variable (X2) has a positive and not significant influence on student satisfaction (Y). It shows that the academic services of STIKOM Bali felt by Dual Degree students are known to be good and able to answer the needs of students for the fulfillment of the academic services, but not to provide a significant influence on the satisfaction of Dual Degree program students.

3. The contribution of leadership policy variable (X3) has a positive and significant influence on student satisfaction (Y). It shows that the policies that have been made by the leaders of STIKOM Bali are able to answer the rights needs of STIKOM Bali students, in the academic learning process, as well as self-development gained outside the learning process in the classroom.

4. The contribution of facilities and infrastructure variable (X1) has a positive and not significant influence on student achievement $(Z)$. It shows that the facilities and infrastructure provided by STIKOM Bali, especially in supporting the learning process in the classroom and student self-development are felt to contribute. However, there are still a number of infrastructures provided for students which are considered to be less than the maximum utilization, thus, giving insignificant value to student achievement.

5. The contribution of academic services variable (X2) has a positive and not significant influence on student achievement (Z). It shows that academic services received by Dual Degree students are felt to contribute to the process of achieving student achievement. However, there are still a number of things in academic services that are considered to be unable to answer the needs of students, thus, the contribution of academic services is less significant for student achievement.

Wijayanthi, N. P. P. A., Astawa, I. N. D., Suardana, I. B. R., \& Sunariani, N. N. (2019). Service satisfaction towards student achievements of dual degree program Stikom Bali. International Research Journal of Management, IT and Social Sciences, 6(1), 86-94. https://doi.org/10.21744/irjmis.v6n1.598 
6. The contribution of leadership policy variable (X3) has a positive and significant influence on student achievement $(Z)$. The direct contribution of leadership policy has a positive and significant influence on student achievement. It shows the magnitude of attention of the leaders of STIKOM Bali in terms of providing support to students of Dual Degre program felt good by students and can support in the process of achieving their achievements.

7. The contribution of student satisfaction variable $(\mathrm{Y})$ has a positive and significant influence on student achievement $(\mathrm{Z})$. The contributions to the satisfaction of Dual Degree program students have a positive and significant influence on achievement. It shows in broad outline the satisfaction of Dual Degree program students whose measurements consist of supporting facilities and infrastructure, academic services, plus the attention of the leaders of STIKOM Bali through their policies. It is considered able to answer the needs of students in the process of achieving good results.

Conflict of interest statement and funding sources

The authors declared that they have no competing interest. The study was financed by personal funding.

\section{Statement of authorship}

The authors have a responsibility for the conception and design of the study. The authors have approved the final article.

\section{Acknowledgments}

The authors would like to thank the editors of the International Research Journal of Management, IT and Social Sciences for their support, valuable time, and suggestions. 


\section{References}

Ahmadi, J., \& Hasani, M. (2003). Prevalence of substance use among Iranian high school students. Addictive behaviors, 28(2), 375-379. https://doi.org/10.1016/S0306-4603(01)00246-5

Bass, R. F. (2011). Stochastic processes (Vol. 33). Cambridge University Press.

Charolina, I. Pelaksanaan Administrasi penjualan pada PT. Perhutani (Persero) KPH Jember/oleh: Inne Charolina.

Engkosworo \& Komariah. (2011). Kontribusi Kebijakan Pimpinan, Kompetensi Dosen, Dan Pelayanan Karyawan Terhadap Penjaminan Mutu Internal Dan Dampaknya Terhadap Kepuasan Mahasiswa Perguruan Tinggi Muhammadiyah BIMA-NTB (Doctoral dissertation, Universitas Muhammadiyah Surakarta).

Ferdinand, A. (2002). Structural equation modeling dalam penelitian manajemen. Semarang: Badan Penerbit Universitas Diponegoro.

Iksan, I. (2013). Kontribusi Kebijakan Pimpinan, Kompetensi Dosen, Dan Pelayanan Karyawan Terhadap Penjaminan Mutu Internal Dan Dampaknya Terhadap Kepuasan Mahasiswa Perguruan Tinggi Muhammadiyah BIMA-NTB (Doctoral dissertation, Universitas Muhammadiyah Surakarta).

Khulaimah. (2009). Analisis Tingkat Kepuasan Siswa dan Motivasi dalam Pembelajaran Kelompok (Cooperative Learning) dan Kaitannya dengan Hasil Belajar Akuntansi di Smklabor Binaan Fkip Unri Pekanbaru. Jurnal Pendidikan Ekonomi dan Bisnis, 9(2), 77-90.

Moenir, A. S. (2010). Manajemen pelayanan umum di Indonesia. Bumi Aksara.

Safi'i, I., \& Handoko, F. (2017). Kualitas Pelayanan Di Tinjau Dari Prestasi Akademik Mahasiswa Studi Kasus Pada Universitas Kadiri. Jurnal Teknologi dan Manajemen Industri, 1(2), 22-27.

Slamet, A. (2003). Analisa laporan keuangan.

Sopiatin, P. (2010). Manajemen belajar berbasis kepuasan siswa. Bogor: Ghalia Indonesia.

Srinadi, N. L. P. (2015). Analisis pengaruh penggunaan teknologi informasi sebagai media pembelajaran terhadap motivasi belajar siswa. Proceedings Konferensi Nasional Sistem dan Informatika (KNS\&I).

Sugito, M. (1982). Nihongo Akusento no Kenkyuu [Studies on Japanese Accent]. Tokyo: Sanseido.

Supriadi, E. (2017). Kontribusi kepemimpinan kepala madrasah, kemampuan kerja guru dan iklim organisasi terhadap prestasi belajar siswa mts negeri jakarta selatan. Tanzhim, 1(02), 1-18.

Syaodih, N. (2009). Metode penelitian pendidikan. Bandung: PT. Remaja Rosdakarya.

Tuerah, M. C. (2015). Analisis pengendalian persediaan bahan baku ikan tuna pada CV. Golden KK. Jurnal EMBA: Jurnal Riset Ekonomi, Manajemen, Bisnis dan Akuntansi, 2(4).

Wijaya, P., \& Purnawati, N. K. (2014). Pengaruh Likuiditas dan Kepemilikan Institusional terhadap Nilai Perusahaan Dimoderasi oleh Kebijakan Dividen. Jurnal Manajemen Universitas Udayana, 3768-3780.

Wijayanthi, N. P. P. A., Astawa, I. N. D., Suardana, I. B. R., \& Sunariani, N. N. (2019). Service satisfaction towards student achievements of dual degree program Stikom Bali. International Research Journal of Management, IT and Social Sciences, 6(1), 86-94. https://doi.org/10.21744/irjmis.v6n1.598 


\section{Biography of Authors}

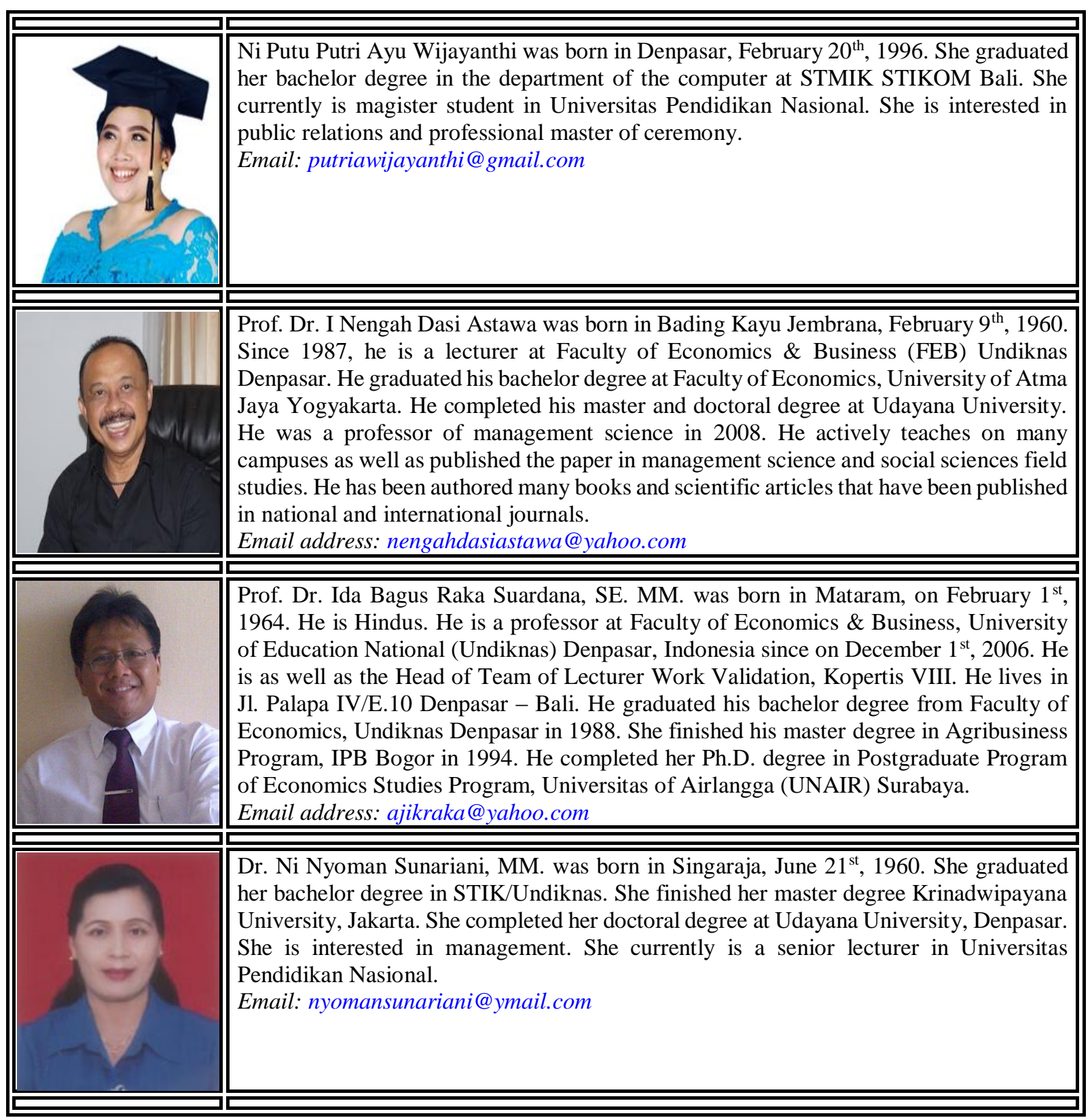

